\title{
TODAY'S HIGHER EDUCATION AT A CROSSROADS: IS THE EDUCATOR'S ROLE UNDERGOING A PARADIGM SHIFT?
}

\author{
Cezar Scarlat \\ PhD, Director, Doctoral School of Entrepreneurship, Business Engineering \& Management - \\ FAIMA, University "Politehnica” of Bucharest (Romania)
}

\begin{abstract}
The education is currently under the pressure of environmental forces that induce challenging and rapid changes; these changes are interlinked, and influence or are influenced by the education systems and processes - in all their dimensions: students, educators, teaching infrastructure and methods. The higher education has to answer to new challenges and most answers gravitate around getting the best compromise between traditional versus new education technologies. If the blended learning seems to be a common sense solution applicable in several instances, a question stands still: If the source of information/knowledge can be quasi-instantly accessed then how to deal with this tremendous amount of data which develops exponentially in time? What should be the educator's role in the next future?

From the educator's standpoint, focused on the educator's role, observing the different progress rates of the available data, information and knowledge (on one side) and human capacity to process these available data, information and knowledge (on the other side), the author becomes aware of the higher pace of the first - in the midst of impetus of new communication and information technologies - and argues that, at this point in time, we are eye-witnessing a real education paradigm shift. The education system is at a critical point in time (call it critical point of education - CPE) when the educator's role must change from knowledge repository to skilled, expert knowledge explorer and identifier, switching from teaching the subject to teach students how to pick the right and relevant information related to the subject - from the ocean of available data.

Besides all the above questions, this paper launches the thesis of the education paradigm shift - in that respect of the educator's role in the predictable future, to provoke a discussion, and to open a research path, for higher education strategists, policy makers, scholars and educators.
\end{abstract}

Keywords: Higher education, educator's role, education paradigm shift, critical point of education $(C P E)$.

\section{Introduction}

Nowadays, the education, in general, (and the higher education, in particular) has to answer to the new challenges: How to cope with the discrepancy between the best universities and decreasing population in the developed countries (on one side) versus (on the other side) relatively less and not-so-good universities targeted by a booming population in the less developed countries? How to keep the pace with the best sustainable compromise (of economic development) between new technologies development and climate change? How to answer to the latest needs of the global economy, while careers change themselves (Pascadi \& Scarlat, 2016)? How to rapidly adapt to the continuously and fast changing requirements of the new jobs associated to the state-of-the-art technologies? Ultimately, how will the education-related jobs of the future change?

Different evolving paths open controversial yet creative debates on hot subjects like: virtual university versus 'bricks-and-mortar' traditional university; entrepreneurial versus classical university; long-life learning versus formal education; free versus paid education; mass (uniform) versus elite (differentiated) education; e-books and virtual libraries versus paper books and traditional libraries; high-tech online platforms versus traditional teaching methods; virtual versus on-site educational tours, and the list is open (Burke \& Shay, 2016). However, the common sense should prevail and answers gravitate around getting the best compromise (as effectiveness and efficiency) between apparently opposite elements (traditional versus modern). Some answers are trivial while others lie in the technology itself. 
If the blended learning seems to be a balanced solution applicable in several instances (education infrastructure, teaching materials and methods), a particular question stands still: If the source of information (source of knowledge, ultimately) can be almost instantly accessed then how to cope with this tremendous amount of data?

The paper objective is to launch the thesis of education paradigm shift - in that respect of the educator's role in the predictable future. Consequently, the remaining of this chapter is deals with: middle age universities as shapers of the modern higher education; the evolution of the educator's role and the paradigm shift in its evolution (the higher education at crossroads), followed by conclusions.

\section{Universities: The oldest and most enduring organizations}

As compared to other types of organizations, the educational institutions are among the oldest. Some precursors of traditional universities are still active (as The King's School, Canterbury, England, since 597). The oldest, still functioning universities are considered: Al-Azhar University in Cairo, Egypt (970/972); University of Bologna, Italy (1088); University of Oxford, England (1096/1167); University of Salamanca, Spain (1134) - on top of others that have followed. The middle ages universities have not emerged from scratch (Courtenay and Miethke, 2000); it is generally accepted that modern universities have the roots in the mid-age Christian tradition (Rüegg, 1992) and their precursors were religious (cathedral or monastic) schools, dating back in the $6^{\text {th }}$ century (Riché, 1978). Evolved from the religious schools created by cathedrals for the clergy education in the Middle Ages, the proper universities were established in towns and defined as 'communities of teachers and students' similar to professional guilds. They were self-regulated and neatly organized, their constitutions providing clear admission procedures (like in guilds). In spite of the university autonomy and academic freedom, the clearly admission and functioning rules as well as the professionalism of its members (respect for their profession included) all made universities very well organized and managed, apparently rigid institutions (Tolar, 1980).

Universities are among the oldest as well as enduring institutions. They prevailed over wars, famine, plagues, extreme natural adversities, or dramatic changes of political regimes: "Many of the higher education institutions ... have outlasted communism itself. Although universities ... are not known for rapidly embracing change, once they do expend the effort to incorporate new philosophies, change has a lasting effect." (Tolar, 1998, p.161) The enduring paradox (most advanced ideas and top research versus rigidity) is explained exactly by the freedom of creative spirit - allowed by the framework of precise (not rigid) internal rules. Universities do not change themselves but they change the environment.

\section{The educator's role: From the wise man to magister to university professor. What after? Higher education at crossroads: A paradigm shift in the educator's role!}

Besides family education (in general basic), the role of school educator has shifted in time from magister teaching disciples (Greek-Roman antiquity) to professor encyclopaedicus (middle age's Erasmus of Rotterdam) to contemporary university professors mastering (at their best) a single subject. Today, new sciences and deeper areas of knowledge are established in each sector of science, because of unprecedented volumes of information in each of them - so that it is almost impossible that a contemporary university professor to master more than a single subject, a very few or a narrow knowledge area. It seems that our society is about reaching a critical point in time; not necessarily as technology management but as information management in education. This happens when the amount of available information is larger than the amount of knowledge homo sapiens needs (limited to the amount of information his brains are able to process or the brains' processing capacity). Both figures - the amount of available information (A) and the brains' processing capacity (B) - display positive dynamics, yet the first one (A) features a lot higher, accelerated pace: undoubtedly, the volume of available information is the result of the accelerated progress of science/sciences and technology/technologies (currently, IT\&C - that includes internet communication, social technologies, artificial intelligence, cloud and quantum computing - but also genetic engineering, biotechnology). On the other hand, the amount of information that human brains are able to process (B) - in order to turn it into knowledge - is linked to the human DNA. Per Hawking (2001), the complexity of DNA improved over time, as measured in bits of information: from 1 bit/100 years (during first two billion years since emergence of life on Earth) to 1bit/year (during last few million years) - as result of random mutations and natural selection.

The relatively low pace of improving the DNA complexity suggests a relatively linear increase in brains capacity to process the information. In this matter, following to earlier studies (Hick, 1952), Moscoso del Prado (2011) estimates the human reaction time at maximum $60 \mathrm{bit} / \mathrm{s}$, observing that it depends on tasks to be fulfilled, and it possibly be higher (yet not claiming any upper limit). To note that 
invention of writing was crucial exactly because it made possible to transmit information along generations without expecting the slow progress of the DNA complexity.

Consequently, as (A) is currently increasing exponentially while (B) displays relatively linear increase, it is expected that, at a certain point in time, the first curve intersects the second. Define this intersection point of the two curves above as critical education point (CEP). It means that homo sapiens is not able to cope anymore with exponentially increased volumes of available data and information produced by novel technologies. Of course, computers with their processing power and larger and larger memory devices help to a certain extent to enhance and amplify the human capacity. However, realistically, the question stands still: How can the educator cope nowadays with such tremendous deal of information (impossible to be processed by a single person)? How could the educator ask students to do what $\mathrm{s} /$ he cannot do? What should be the educator's role in the foreseeable future? Should we call him/her still educator? Ultimately, will the educator have any roll of any kind? Here's the paradigm shift! We currently are eye-witnessing a real paradigm shift in education, related to the educator's role.

The author's opinion is that education system is currently at a critical point in time when the educator's role must change from knowledge repository to skilled, expert knowledge explorer and identifier. The educator will continue to exist in the near future at least, but with a different role.

First and foremost, s/he has to be familiar with new teaching technologies (not only e-learning platforms but also diverse devices for AI - artificial intelligence, VR - virtual reality, AR - augmented reality) and teach students how and when to use them. Then, the educator has to switch from teaching the subject to teach and guide students how to pick the right information related to the subject from the ocean of data, literally; to distinguish the better from poor quality, the true from false information, and eliminate the fake data.

In the near, foreseeable future, the role of educator is not going to be diminished; exactly the opposite is the case: the educator's role becomes more complex, to teach how and when to wisely manage the technology tools in general; how and when to use the newer technologies as online and mobile teaching, AI, AR and VR devices; to promote experiential teaching together with students in order to effectively guide them to achieve the educational objectives. Pacansky-Brock (2017) explains how educators need to understand the applicability of the new educational technology-based tools (as social media and web 2.0 technologies) that are currently transforming the learning trends and preferences of students as well. The public web and open educational resources are going to replace the traditional learning management systems and technologies that no longer exist; and their mastering should be on the educator's list of competencies - in order to enhance "communications with and between students, and cultivating participatory, student-centred learning activities".

Acknowledging the changes in the student body from Millennials to Gen $Z$ or $i$ Gen, Fleck and Kakouris (2019) propose the use of adequate experiential teaching innovations (such as use of music and art to teach; use of art to trigger critical reflection; use of the superhero to stimulate creativity; use of alternative media such as film and TV to engage students), specifically engaging and inspiring students toward business venturing. Other educators' experience demonstrates that experiential learning (Kolb, 1984) is applicable to various areas of teaching (Itin, 1999; McCarthy and McCarthy, 2006; Breunig, 2009; Stremba and Bisson, 2009; Smith Budhai and Brown Skipwith, 2017). Bartels and Wagenaar (2018, p.191) describe "three pedagogical practices for recognizing and tolerating affective resistances to experiential learning and finding creative solutions to emergent research problems".

The idea of combining the real and the virtual (Tavangar, 2014) by use of VR (Virtual Reality) and AR (Augmented Reality) technologies and their tools in education is opening unlimited horizons. Considering the advantages that come with the growth of artificial intelligence (AI), Harasim (2017) regards connectivism as a learning theory and renames the theory of online collaborative learning as collaborativism. Starkey (2012) explores the perspective of knowledge transfer and pedagogy within digital context, and underlies the importance of critical thinking during digital age - while considering both online and face-to-face interactions. Based on faculty interviews, Ko and Rossen (2017) focus their research on teaching massive open online courses (MOOCs) using open educational resources, learning analytics, and online tools (multimedia and mobile devices among them).

The issue of sustainability is studied in case of mobile technologies ( $\mathrm{Ng}$ and Cumming, 2015), which are one of the fastest growing areas of technology used in education: the main challenges are the significant investments in mobile devices and associated technologies that should be made by the university, time and training required to initiate mobile learning programmes, and the fast pace of technology changes (associated with new rounds of investments). On the other side, the easy access of larger number of students, regardless of location, is an important advantage.

About three decades ago, Wiener (1989, p.58) observed that people "spend what may amount to forty per cent of this normal life as a learner ... It is as completely natural for human society to be based on learning as for an ant society to be based on inherited pattern." 
Only a generation later, we acknowledge the principle of LLL (Long Life Learning). Counter-intuitively, the technology progress is not going to shorten the duration of learning (as compared to the life span) for at least two reasons: increased complexity of [science and technology] knowledge, and higher pace at which volumes of data outpace the learning capacity of human brains. The solutions are on all sides: automatization of the education process and making it more effective and efficient; use of more advanced, technology-based education methods, as seen above; use of working machines (robots) able to learn at a higher pace than humans do. Hence, a new category of challenges for scientists: developing learning languages for other than inter-human communication: but for man-to-machine, machine-to-man, and even machine-to-machine communication, dealing with both phonetic and semantic aspects of language (Wiener, 1989, p.74). Consequently, there is a need for more educators, for longer periods of time, able to play a newer, more complex role. In addition, suitable online teaching programmes have to be developed, in line with the university mission (King and Alperstein, 2014).

Summarizing, the near-future-educator should:

- Master new education technologies.

- Be able to use new teaching technologies.

- Be able to teach students how to use the new learning technologies.

- Know to discern between: true versus false, fake or misleading information; important versus not important information; relevant versus not relevant for the discussion.

- Be able to teach students how to discern themselves.

- Mentor and guide rather than simply teach the students.

On the other side, the people will live longer (de Grey \& Rae, 2007) and, eventually, think about becoming immortal (Fossel, Blackburn \& Woynarowski, 2010; Cave, 2012; Popescu \& Scarlat, 2017). Other than trivially enjoying the life, living longer means more time to cope with larger and larger volumes of information and to learn more (i.e. more time for education), to have more time to apply the acquired knowledge. Strictly, in terms of education, other questions arise: How will education look-like in the longer run and how its components will evolve? The answers are all beyond the goal of this paper. Therefore, the objective is limited to launch the thesis of education paradigm shift - in that respect of the educator's role in the predictable future - in order to provoke a discussion on this subject, and, eventually, to open a research path, for [higher] education strategists, policy makers, scholars and educators.

\section{Conclusions}

In the near, predictable future, the education system (as part of the human society) will continue its mission and address the needs of the increasingly technologized society, while the educator's role is undergoing a paradigm shift: from educator to master of new technologies as well as students' mentor and guide to discern the right information from the available ocean of mixed information.

On longer run, the future education will depend on future technologies and their impact on the human society, but mostly decisions made by humans. Therefore, the education system and educator's role will significantly depend on how the future humans (both educators and students) will evolve - either still homo sapiens or different species adapted to the radical technology changes. The human race suffocation or extinction as result of wrong technology decisions is an extreme possibility (Wiener, 1989; Martenson, 2011; Harari, 2016). Is it to cope with sustainable technology development as homo sapiens or is going to be a different community of homo networkingus or homo cyberneticus?

Today, the higher education is at a crossroads. The humans are actually in front of largely spread options: within the angle between wiseman and cyborg, hopefully, the common sense will prevail.

It is up to contemporary educators, it is their educative mission and mentoring role to steer younger generations to make the right decisions for the future.

\section{References}

Bartels, K.P.R. \& Wagenaar, H. (2018). Doubt and excitement: an experiential learning approach to teaching the practice of qualitative research. Qualitative Research, 18(2), pp.191-206. (First published online: June 30, 2017)

Breunig, M.C. (2009). Teaching Dewey's Experience and Education Experientially. In B. Stremba \& C.A. Bisson (Eds.), Teaching Adventure Education Theory: Best Practices (pp.122-127). Champaign, IL, USA: Human Kinetics.

Burke, P.J. and Shay, S. (Eds.). (2016). Making Sense of Teaching in Difficult Times. New York, USA: Routledge. 
Cave, S. (2012). Immortality: The Quest to Live Forever and How It Drives Civilization. New York, USA: Crown Publishers.

Courtenay, W.J. \& Miethke, J. (Eds.). (2000). Universities \& Schooling in Medieval Society. Leiden-Boston-Köln, Netherlands: Brill.

de Grey, A. \& Rae, M. (2007). Ending Aging: The Rejuvenation Breakthroughs that Could Reverse Human Aging in Our Lifetime. New York, USA: St. Martin's Press.

Fleck, E. \& Kakouris, A. (2019). Implementing Experiential Teaching Innovations to Encourage Entrepreneurial Activity. Pre-Conference Workshop presentation, the $14^{\text {th }}$ European Conference on Innovation and Entrepreneurship (ECIE 2019), Kalamata, Greece. Retrieved July 11, 2019, from: https://www.academic-conferences.org/conferences/ecie/ecie-workshops/

Fossel, M., Blackburn, G. \& Woynarowski, D. (2010). The Immortality Edge: Realize the Secrets of Your Telomeres for a Longer, Healthier Life. Hoboken, NJ, USA: John Wiley.

Harari, Y.N. (2016). Homo Deus: A History of Tomorrow. London, UK: Harvill Secker.

Harasim, L. (2017). Learning Theory and Online Technologies (2 ${ }^{\text {nd }}$ Edition). New York, USA: Routledge.

Hawking, S. (2001). The Universe in a Nutshell. The inspiring sequel to A Brief History of Time. London, UK: Bantam Press.

Hick, W.E. (1952). On the rate of gain of information. Quarterly Journal of Experimental Psychology, 4(1), pp.11-26.

Itin, C.M. (1999). Reasserting the Philosophy of Experiential Education as a Vehicle for Change in the $21^{\text {st }}$ Century. The Journal of Physical Education, 22(2), pp.91-98.

King, E. \& Alperstein, N. (2014). Best Practices in Online Program Development. Teaching and Learning in Higher Education. New York, USA: Routledge.

Ko, S. \& Rossen, S. (2017). Teaching Online. A Practical Guide (4 ${ }^{\text {th }}$ Edition). New York, USA: Routledge.

Kolb, D. (1984). Experiential Learning: experience as the source of learning and development. Englewood Cliffs, NJ, USA: Prentice Hall.

Martenson, C. (2011). The Crash Course: The Unsustainable Future of Our Economy, Energy, and Environment. NJ, USA: Wiley, Hoboken.

McCarthy, P.R. \& McCarthy, H.M. (2006). When Case Studies Are Not Enough: Integrating Experiential Learning into Business Curricula. Journal of Education for Business, 81(4), pp.201-204.

Moscoso del Prado Martin, F. (2011). Macroscopic thermodynamics of reaction times. Journal of Mathematical Psychology, 55(4), pp.302-319.

Ng, W. \& Cumming, T.M. (2015). Sustaining Mobile Learning. Theory, research and practice. London, UK: Routledge.

Pacansky-Brock, M. (2017). Best Practices for Teaching with Emerging Technologies (2 ${ }^{\text {nd }}$ Edition). Routledge, New York, USA.

Pascadi, M.V. \& Scarlat, C. (2016). Meta-Strategies for Career-Oriented Collaboration. FAIMA Business \& Management Journal, 4(4), pp.43-48.

Popescu, F. \& Scarlat, C. (2017). Human Digital Immortality: Where Human Old Dreams and New Technologies Meet. In A. Mesquita (Ed.), Research Paradigms and Contemporary Perspectives on Human-Technology Interaction, Chapter 12 (pp.266-282). Hershey PA, USA: IGI Global.

Riché, P. (1978). Education and Culture in the Barbarian West: From the Sixth through the Eighth Century. Columbia, SC, USA: University of South Carolina Press.

Rüegg, W. (1992). Foreword. The University as a European Institution. In A History of the University in Europe, Vol.1: Universities in the Middle Ages (pp.XIX-XX). Cambridge, UK: University Press.

Smith Budhai, S. \& Brown Skipwith, K.'A. (2017). Best Practices in Engaging Online Learners through Active and Experiential Learning Strategies. New York, USA: Routledge.

Starkey, L. (2012). Teaching and Learning in the Digital Age. London, UK: Routledge.

Stremba, B. \& Bisson, C.A. (Eds.). (2009). Teaching Adventure Education Theory: Best Practices. Champaign, IL, USA: Human Kinetics.

Tavangar, H. (2014). The Out of Eden Walk: An Experiential Learning Journey from the Virtual to the Real. Edutopia, January 3. Retrieved July 11, 2019, from https://www.edutopia.org/blog/out-ofeden-experiential-learning-homa-tavangar

Tolar, R.L. (1980). An Analysis of the Major Problems of Academic Consortia in Higher Education. Unpublished PhD thesis. Eugene, OR, USA: University of Oregon.

Tolar, R.L. (1998). SME Assistance Strategies: Why Working with Universities in Emerging Democracies Makes Sense. In C. Scarlat, Specialization \& Cooperation Strategies in Industry and Services, Annex 2 (pp.158-161). PhD thesis. Bucharest, Romania: University "Politehnica" Press.

Wiener, N. (1989). The Human Use of Human Beings. Cybernetics and Society [Reviewed version, with a new Introduction by Steve J. Heims]. London, UK: Free Association Books. [First published 1950, Boston, MA, USA: Houghton Mifflin]. 